\title{
The Modeling of Information Security Classification with Risk Value Assessment Factor to Good Information Governance on the Indonesia Higher Education
}

\author{
IGN Mantra ${ }^{+}$ \\ Perbanas Institute, Jakarta, Indonesia
}

\begin{abstract}
Digital information is currently dominating the turnover or circulation of information in any institution, whether in government, private sector, universities, Social, Defense and Security, Economy, Politics etc. Almost certainly the information is spearheading the movement of the economy, "who holds the information then he will win the war". Today's Internet era, which is highly sought after by the hackers or crackers and intruders is information, the heart of the information in the database, computer and laptop is not worth more in the eyes of hackers or crackers, hackers either individual or team will try to break through the defense and security information in server, they are vying to be able to obtain important information, and even the most sensitive secrets though. The purpose of the security classification of information is made rating models on levels of sensitivity of the information, with the security classification of information would make the control of the security protection of data and information, the classification will do with risk value assessment factor so that information can be saved away from the hands of scavengers information especially in Indonesia higher education sector.
\end{abstract}

Keywords: information security classification, information governance, information security policy, IT security risk management, risk value assessment factor.

\section{Introduction}

In the context of information security, information security classification based on the level of sensitivity of the information and the impact if the information is revealed/opened by people who do not have legal authorization so that information can be categorized been a leak of information.

There are several approaches to classify the security of informations depends on the country and the institutions do, classification of information on military and security industry is very different from the Banking and Finance Industry including other institutions such as education and health.

\section{Background}

Information is necessary to be classified, there are several important reasons behind the classification is as follows:

1) To protect the Personal Information, whoever and wherever citizen to get protection in the law of Information Technology and Electronics, personal information such as Medical Record, Data Banks, detailed data clerks, students are well guarded by the owner of the information system. Moreover, the personal database state officials may not be republished without permission[1].

2) To protect the information from unauthorized access is allowed, classification restricts information to everyone and not to access parts information indiscriminately, accesses to the database are arranged so that should only be accessible to any interested operator, for example, telephone customer service, banking, hospitals can only access such information with the consent of the

\footnotetext{
+ Corresponding author. Tel.: +62 8158009575 .

E-mail address: ignmantra@gmail.com,ign.mantra@perbanas.id
} 
customer in front of their screens, and even then only to the extent necessary information, such as saving savings entry, customer database load being complain, customer data load Hospital etc.

3) To protect the intellectual property rights, at the time the information has been generated by the institution, the information relating to the work of individual and institutional copyright must be maintained properly, because copyrighted works is an asset of the company, before it gained recognition as a right of a copyright work, the work of the government should be saved and properly supervised in order not to fall to the competitors and the edges are each claim to the copyright work [2].

4) To protect the leakage of information and dissemination of such information, the information can leak or transfer from one place to another without realizing it and want, at any institution should be able to do well because the classification information is not confidential information carelessly placed and can be stolen by others as well as employees, information has a very high value and can be leaked accidentally or intentionally, recklessly not copy important information into Flash Disk personal and brought to and fro, the probability of lost and forgotten plugged into the computer in general very harmful information in in the flash disk.

5) To provide the facilitation for internal information exchange and integrated services at the time the information is sent / received, information that has been produced by each department should to be interchangeable between departments, with the rules of classification of information is not just information can be sent / received, must go through strict procedures, classification of information is helpful in order not to move information to unauthorized and ends is leaking information to the other party.

6) To protect the information in the form of support for public security and law enforcement, the classification of the information would put the information on the actual place so that the necessary safeguards on who will have access to such information, if there is a violation of misuse of the information classification should be imposed for violations of the law enforcement has been done, such as the classification of information "top secret", should not be just anyone to know that information, it could be nuclear pin, pin cruise missiles, pin chemical bombs, guns and force development plans, plans transfer of combat equipment, broken equipment and maintenance, the amount of organic weapons and non-organic, document new discoveries, investment, human resources involved etc. must be very concealed its existence [3].

\section{Method}

Methodology to be used for this research is a model of constructive research, analysis of important information and sensitive owned by the education sector, making the rating sensitivity of the information security and information security ultimately make a classification of all asset information held by the higher education sector.

The method used in this study is constructive research, conduct studies and calculations that IT risk management has been owned by Higher Education institutions, and then create a security classification of the information in the information security governance.

Analysis of the IT risk management will acquire high risk, moderate and low for information security classification can be made applicable in many institutions university.

Security classification information obtained will clarify which information will be placed on information security classification model conditions suitable for the university.

\section{Implementation}

Information Security classification at Universities in Indonesia did not like with the classification in the Military, so in the University was simplified into four levels namely: SECRET, CONFIDENTIAL, RESTRICTED dan UNCLASSIFIED, the framework shows in the Fig. 1.

Meanwhile, to make information security classification and placement the information in the proper category in the universities should be calculated the informations using Information Technology Risk 
Management, it has already done in many organizations [4]. Approach to IT Risk Management calculate using methods Qualitative and Quantitative methods, for Qualitative, Risk value is usually determined by the range :

LOW RISK $=$ Risk received minor $(0)$

HIGH RISK $=$ High-risk accepted (2)

MEDIUM RISK $=$ Risk received medium (1)

SUPER HIGH RISK = Super High-risk accepted (3)

The quantitative methods of risk assessment methods with a mathematical approach. With this method the value of the risk can be calculated using the following formula.

Calculation of the risk with a mathematical approach:

$\begin{array}{ll}\text { Risk value } & =\text { NA x BIA x NT } \\ \text { Business Impact Analysis } & =\text { BIA }\end{array}$

where: Asset value $=\mathrm{NA}($ Nilai Asset $),=\mathrm{NC}+\mathrm{NI}+\mathrm{NV}$

Threat Value $\quad$ NT

\section{Calculation:}

1. The kind of qualitative information so classification of information security classification is

Honor credits per each faculty (Lecturers are not fixed)/file $\rightarrow$ so, the asset value is LOW RISK $(0)$.

2. The kind of quantitative information so classification of information security classification is

Mail Server, calculation:

Nilai Ancaman (NT, threats value),

Confidentiality: Internal user only $(N C=1)$

Nilai Asset (NA, asset value $)=N C+N I+N V$

Nilai Ancaman $(N T)=\mathbf{\Sigma} P O \times \mathbf{\Sigma}$ Anca.

Nilai Resiko (NR, risk value),

$\begin{array}{ll}\text { Asset value }(N A)=8 & \text { BIAvalue }(\text { BIA })=60 \\ \text { The obtained val of the risk for MailServ } & \text { Risk value (Mail Serv) }=\end{array}$
Integrity : Mayor disturbance $(N I=3)$

$=1+3+4$,

$N T$ (mail server) $=\mathbf{\Sigma} P O / \mathbb{\Sigma}$ Anca.
Availability : Very high Avail. $(N V=4)$

$=8$

$=2.1 / 6, \quad=0.35$

Threat values $(N T)=0.58$

$=8 \times 60 \times 0.58, \quad=278.4$

Fig. 1. Information Security Classification Framework for Indonesia Higher Education Sector.

In higher education [7] needs to be compiled first asset owned information such as in list:

a.Diploma Certificate/file

b.Transcript values (values that have been processed)/file

c.Value of raw (unprocessed value) / original value of the lecturer/file

d.Professors Data archive (especially tenured faculty)/file

c.Operating licenses and permits establishment Studies Colleges/file

d.Basic salaries of tenured faculty (energy e.functional) and support personnel/file

f.Honor credits per each faculty (Lecturers are not fixed)/file

g.Computer Laboratory/file

h.Laptop or PC computer structural employees (Rector, Vice

Rector, Director, Chairman of the

department, BAAK, and finance)/file

j.Computer Server as Web Server, Database Server, Email Server etc.

k.Academic guidelines, final project, and so forth.

LCD Projector/file
1.Student and grades database m.Library books database

n.Books Catalogs

o.Subjects per semester (the curriculum) database

p.Alumni database

q.Student financial database

r.Office inventory database

s.Data extracurricular activities of students database

t.Certificate lecturer in performing community service/file

u.Research Data lecturers/file publications

v..Certificate of accreditation from the BAN PT/file

w.Marketing Information

x.Academic Calender Information

y.ISO 9001:2008 Documentations

z.Lecturer and Student presence

aa.Employee presence

bb.Project Research

cc.Institution Budgeting 
The implementation of the security classification of the information depends on the individual institution, following the author decrypt reset in accordance with the references used in several countries, so it can be used as reference material in the Indonesia classification information.

Implementation is divided into several sections such as doing: 1. Labeling, 2. Storage, 3. Transmission, 4. Destruction that has not been used, 5. Protecting the integrity, 6. Licensing limited access and disclosure, 7. Establish accountability.

\section{Result}

To be able to place the exact position of the critical information necessary to rating based Risk owned by each such information, the risks can be computed qualitative (can not be calculated the value of an information / assets) and quantitative (can be calculated price of an information / assets) [5].

Results perform information security classification of the various asset information in the higher education sector as follows:

Table I: The Information Security Classification for Indonesia Higher Education

\begin{tabular}{|c|c|c|}
\hline Classifications & Asset Description of Information & Information Detail \\
\hline UNCLASSIFIED & $\begin{array}{l}\text { The informations are open to the public, to all } \\
\text { university employees and non-employees, to } \\
\text { university contractors and subcontractors, agents, etc. }\end{array}$ & $\begin{array}{l}\text { Marketing Information, } \\
\text { Lecturer and Student presence } \\
\text { Academic Calender Information }\end{array}$ \\
\hline RESTRICTED & $\begin{array}{l}\text { The informations are limited just to name personnel / } \\
\text { team designated course to be open information. } \\
\text { Provide limited access for contractors and } \\
\text { subcontractors, agents, suppliers, etc. }\end{array}$ & $\begin{array}{l}\text { Books Catalogs } \\
\text { Diploma Certificate/file } \\
\text { Transcript values (values that have been processed)/file } \\
\text { Value of raw (unprocessed value) / original value of the } \\
\text { lecturer/file } \\
\text { Professors Data archive (especially tenured faculty)/file } \\
\text { Operating licenses and permits establishment Studies Colleges/file } \\
\text { Computer Server as Web Server, Database Server, Email Server. } \\
\text { LCD Projector/file } \\
\text { ISO 9001:2008 Documentations }\end{array}$ \\
\hline CONFIDENTIAL & $\begin{array}{l}\text { The informations are very limited to personnel and } \\
\text { teams involved only in the access and functionality } \\
\text { such information. }\end{array}$ & $\begin{array}{l}\text { Basic salaries of tenured faculty (energy functional) and support } \\
\text { personnel/file } \\
\text { Honor credits per each faculty (Lecturers are not fixed)/file } \\
\text { Computer Laboratory/file } \\
\text { Laptop or PC computer structural employees (Rector, Vice Rector, } \\
\text { Director, Chairman of the department, BAAK, and finance)/file } \\
\text { Data extracurricular activities of students database } \\
\text { Certificate lecturer in performing community service/file } \\
\text { Library books database } \\
\text { Project Research } \\
\text { Institution Budgeting } \\
\text { Research Data lecturers/file publications } \\
\text { Employee presence }\end{array}$ \\
\hline SECRET & $\begin{array}{l}\text { The informations are very limited only to a few } \\
\text { personnel are allowed access to such information. }\end{array}$ & $\begin{array}{l}\text { Student and grades database } \\
\text { Student financial database } \\
\text { Office inventory database }\end{array}$ \\
\hline
\end{tabular}

The Information security classification for the type qualitative classification as follows:
UNCLASSIFIED = LOW RISK (0)
CONFIDENTIAL $=$ HIGHRISK (2)
RESTRICTED = MEDIUM RISK (1)
SECRET = SUPER HIGH RISK (3)

After the making of the information security classification we can make a classification matrix based on categories and the planning application to be made to follow the standard Information Security clasification agreed and defined by each institution.

\section{Protecting the integrity of information}

The integrity of information is protected so that information remains current, complete and unchanged (as original), information is accessed and stored in the system information with the principle of "right", so the extent to which user rights to perform "modify" (edit, insert, delete) or "read only". Significant threats to the integrity of that file are stored in a "read only", to modify the file can only be done by the creator of the course, control access rights to the file is set based on user accounts and workgroups as well as physical access to special equipment, while file/ document transfer its integrity must be maintained because it could be a document intercepted by others who are not entitled. To maintain the integrity of many enterprise do encryted to files/ documents are "restricted" when it is transmitted to the other party or stored somewhere. 
Table II: Risk Value Factor Calculation

\begin{tabular}{|c|c|c|c|c|c|}
\hline \multirow{2}{*}{ No. } & \multirow{2}{*}{ Descriptions } & NA & B IA & NT & NR \\
\hline & & Asset Value & & Threat Value & Risk Value \\
\hline 1 & Diploma Certificate/file & 6 & 40 & 0.30 & 72.00 \\
\hline 2 & $\begin{array}{l}\text { Transcript values (values that have been } \\
\text { processed)/file }\end{array}$ & 9 & 30 & 0.40 & 108.00 \\
\hline 3 & $\begin{array}{l}\text { Value of raw (unprocessed value) / original } \\
\text { value of the lecturer/file }\end{array}$ & 3 & 6 & 0.32 & 5.70 \\
\hline 4 & $\begin{array}{l}\text { Professors Dat a archive (especially tenured } \\
\text { faculty)/file }\end{array}$ & 4 & 6 & 0.35 & 8.40 \\
\hline 5 & $\begin{array}{l}\text { Operat ing licenses and permits } \\
\text { establishment Studies Colleges/file }\end{array}$ & 2 & 4 & 0.27 & 2.13 \\
\hline 6 & $\begin{array}{l}\text { Basic salaries of tenured faculty (energy } \\
\text { functional) and support personnel/file }\end{array}$ & 4 & 20 & 0.35 & 28.00 \\
\hline 7 & $\begin{array}{l}\text { Honor credits per each faculty (Lecturers } \\
\text { are not fixed)/file }\end{array}$ & 4 & 20 & 0.35 & 28.00 \\
\hline 8 & Computer Laboratory/file & 3 & 6 & 0.32 & 5.70 \\
\hline 9 & $\begin{array}{l}\text { Laptop or PC computer structural } \\
\text { employees (Rector, Vice Rector, Director, } \\
\text { Chairman of the department, BAAK, and } \\
\text { finance)/file }\end{array}$ & 7 & 60 & 0.45 & 189.00 \\
\hline 10 & Mail Server & 8 & 60 & 0.58 & 280.00 \\
\hline 11 & $\begin{array}{l}\text { Academic guidelines, final project, and so } \\
\text { forth. }\end{array}$ & 3 & 6 & 0.27 & 4.80 \\
\hline 12 & LCD Projector/file & 2 & 4 & 0.25 & 2.00 \\
\hline 13 & Student and grades database & 12 & 100 & 0.65 & 780.00 \\
\hline 14 & Library books database & 4 & 20 & 0.35 & 28.00 \\
\hline 15 & Books Catalogs & 4 & 10 & 0.35 & 14.00 \\
\hline 16 & $\begin{array}{l}\text { Subjects per semester (the curriculum) } \\
\text { database }\end{array}$ & 6 & 40 & 0.37 & 88.00 \\
\hline 17 & Alumni database & 6 & 40 & 0.37 & 88.00 \\
\hline 18 & Student financial database & 11 & 80 & 0.62 & 542.67 \\
\hline 19 & Office inventory database & 6 & 30 & 0.38 & 69.00 \\
\hline 20 & $\begin{array}{l}\text { Dat a extracurricular activities of students } \\
\text { dat abase }\end{array}$ & 5 & 30 & 0.37 & 55.00 \\
\hline 21 & $\begin{array}{l}\text { Certificate lecturer in performing } \\
\text { community service/file }\end{array}$ & 5 & 20 & 0.37 & 36.67 \\
\hline 22 & Research Data lecturers/file publications & 9 & 60 & 0.40 & 216.00 \\
\hline 23 & $\begin{array}{l}\text { Certificate of accreditation from the BAN } \\
\text { PT/file }\end{array}$ & 5 & 8 & 0.37 & 14.67 \\
\hline 24 & Marketing Information & 1 & 4 & 0.17 & 0.67 \\
\hline 25 & Academic Calender Information & 3 & 4 & 0.25 & 3.00 \\
\hline 26 & ISO 9001:2008 Documentations & 6 & 20 & 0.37 & 44.00 \\
\hline 27 & Lecturer and Student presence & 3 & 6 & 0.25 & 4.50 \\
\hline 28 & Employee presence & 3 & 6 & 0.25 & 4.50 \\
\hline 29 & Project Research & 10 & 60 & 0.58 & 350.00 \\
\hline 30 & Institution Budgeting & 10 & 60 & 0.58 & 350.00 \\
\hline
\end{tabular}

The most important thing is the integrity of access control to files/documents to be opened/read, track logs anybody who has opened and transmits the file to the other party, of course file "encrypted" is much safer than clear text transmission. Here is the implementation of Integrity protects information as :

Table III: Information Security Classification and Audit Works for .ID Higher Education

\begin{tabular}{|c|c|c|}
\hline Classifications & Access Restrictions & Audit Works \\
\hline UNCLASSIFIED & $\begin{array}{l}\text { Access to informations are open to the public, to all } \\
\text { university employees and non-employees, to } \\
\text { university contractors and subcontractors, agents, etc. }\end{array}$ & No audit file \\
\hline RESTRICTED & $\begin{array}{l}\text { Access to informations are limited just to name } \\
\text { personnel / team designated course to be open } \\
\text { information. Provide limited access for contractors } \\
\text { and subcontractors, agents, suppliers, etc. }\end{array}$ & $\begin{array}{l}\text { Files/documents audit periodically } \\
\text { monthly or per } 4 \text { months. Read log } \\
\text { files/documents that have been } \\
\text { accessed by personnel/teams. }\end{array}$ \\
\hline CONFIDENTIAL & $\begin{array}{l}\text { Access to informations are very limited to personnel } \\
\text { and teams involved only in the access and } \\
\text { functionality such information. }\end{array}$ & $\begin{array}{l}\text { Files/documents audit periodically per } \\
\text { day / per week to make sure the files } \\
\text { maintained confidential. } \\
\text { Read access log file, who and what } \\
\text { authorize to opening. }\end{array}$ \\
\hline SECRET & $\begin{array}{l}\text { Access to informations are very limited only to a few } \\
\text { personnel are allowed access to such information. }\end{array}$ & $\begin{array}{l}\text { Files/documents periodically per day / } \\
\text { per week to file make sure awake } \\
\text { "secret". Read access log file anyone } \\
\text { who has access. } \\
\text { Replace the passwords and } \\
\text { periodically conduct to encrypt the } \\
\text { file/documents. }\end{array}$ \\
\hline
\end{tabular}




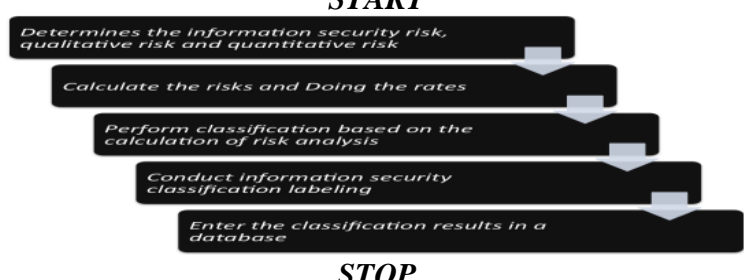

This flow chart to determine the risk of information security, calculate the risks and doing the rating results of the risk analysis. After that perform the security classification of information security risk analysis, and then conduct a security classification labeling and enter this information in a database.

\section{Handling and Processing the Information}

Important to have a good set of procedures to determine the marking and handling of information in accordance with the classification scheme used by the organization [6]. This procedure should include both physical assets and information in electronic format. For each classification, handling procedures should be established, including the following types of information processing operations like, labeling, storage, delivery, archieve and destruction.

Output from systems containing information classified as confidential or important classification should be marked. Flagging generally shaped mark physical. However, some information assets such as documents in electronic format, can not be marked as physical and electronic tagging should be used [7].

\section{Conclusions}

Classification of Information Security, especially in higher education are needed to secure the information itself and makes it easier to access later in the file / document that has been classified. So much vital of information assets as confidential and highly valuable to be protected. The most important of the classification information is anyone who should not open anything, not just anyone should open up and reveal confidential information. In any country in the world there must be a file / document "State Secrets" and no documents to "Public", of course, confidential documents and must not be disclosed to the public and it is not a secret document. The latter is the shared commitment to save the security classification of the information, if there is no commitment and the rule of law there is no point in doing and protect the informations.

\section{References}

[1] AlBone, A. (2010). PEMBUATAN RENCANA KEAMANAN INFORMASI BERDASARKAN ANALISIS DAN MITIGASI RISIKO TEKNOLOGI INFORMASI. Jurnal Informatika, 10(1), 44-52.

[2] Calder, A. (2011). Implementing Information Security based on ISO 27001/ISO 27002. Van Haren.

[3] Clark, D. D., \& Wilson, D. R. (1987, April). A comparison of commercial and military computer security policies. In Security and Privacy, 1987 IEEE Symposium on (pp. 184-184). IEEE.

[4] Dewi, I. K., Fitroh, F., \& Ratnawati, S. (2015). USULAN MANAJEMEN RISIKO BERDASARKAN STANDAR SNI ISO/IEC 27001: 2009 MENGGUNAKAN INDEKS KAMI (KEAMANAN INFORMASI) STUDI KASUS: BADAN NASIONAL PENEMPATAN DAN PERLINDUNGAN TENAGA KERJA INDONESIA (BNP2TKI). SISTEM INFORMASI, 8(1).

[5] Edmonton, Alberta. (2005). Information Security Classification. Information Management Brach Government and Program Support Services Division, Alberta Government Services. Government of Alberta, ISBN 0-7785-3698-X.

[6] Eloff, J. H., \& Eloff, M. (2003, September). Information security management: a new paradigm. In Proceedings of the 2003 annual research conference of the South African institute of computer scientists and information technologists on Enablement through technology (pp. 130-136). South African Institute for Computer Scientists and Information Technologists.

[7] Mohammadian, M., \& Hatzinakos, D. (2009). Data classification process for security and privacy based on a fuzzy logic classifier. International Journal of Electronic Finance, 3(4), 374-386. 